\title{
Az ingatlan-végrehajtás és az ingatlan-nyilvántartás összefüggései - különös tekintettel egyes jogok és jogilag jelentős tények bejegyzésének, illetve feljegyzésének joghatásaira
}

\begin{abstract}
végrehajtás - ingatlan-nyilvántartás - végrehajtási igényper - perfeljegyzés törlési per - hatósági árverés - függő hatály - szerzésmód
\end{abstract}

A bírósági végrehajtás során állami kényszerrel is el kell érni, hogy a pénzfizetésre, illetőleg az egyéb magatartásra kötelezett (a továbbiakban: adós) teljesítse a kötelezettségét. ${ }^{1}$

A bírósági végrehajtás alapvető célja, hogy a végrehajtható okirattal rendelkező végrehajtást kérő követelésének kielégítését szükség esetén állami kényszer útján is biztosítsa. A végrehajtás során az állami kényszer elsősorban az adós vagyoni jogait korlátozza, mely kiterjed arra is, hogy a végrehajtási törvény keretei között az adós vagyontárgyainak és ezen belül legértékesebb jószágának, az ingatlannak a bírósági árverés útján való értékesítésével ezt a célt elérje.

A bírósági végrehajtásnak a végrehajtást kérő és az adós, továbbá a végrehajtás elrendelése és foganatosítása során eljáró személyek és szervek mellett számos egyéb szereplője van. A végrehajtás sikeres lefolytatásához a foganatosítás szakaszában az adós vagyontárgyainak értékesítése során az árverési vevő részvétele alapvető elem. A végrehajtás emellett érintheti mások jogait is, amely jogok adott esetben nem pusztán a végrehajtásra, de az abban részt vevő felekre is kihatnak. $A z$ eredményes és sikeres végrehajtás átfogó elemzése szempontjából nem elegendő a végrehajtásra vonatkozó jogszabályok és ezen belül kiemelten a bírósági végrehajtásról szóló többször módosított 1994. évi LIII. törvény (a továbbiakban: Vht.) ismerete, hiszen a végrehajtási eljáráshoz mint nemperes eljáráshoz a jogrendszer más - mind magánjogi, mind közjogi - normái funkcionálisan szorosan kapcsolódnak.

Jelen tanulmány célja az ingatlanra vezetett végrehajtás és az ingatlan-nyilvántartás összefüggéseinek a vizsgálata. A dolgozat az egyéb források mellett nagyban támaszkodik a Kúria joggyakorlat-elemző csoportja által Az ingatlan-nyilvántartási

\footnotetext{
* Fazakasné dr. Németh Mónika bírósági titkár, Fővárosi Törvényszék, fazakasnem@gmail.com.

1 Vht. 5. § (1) bek.
} 
joggyakorlat-elemző csoport összefoglaló véleménye címmel közzétett véleményére, amely a vizsgálata alá vont eseti döntések és bírói gyakorlat elemzését széles körben és a közigazgatási ügyszak mellett a polgári ügyszakos joggyakorlatra is figyelemmel végezte. ${ }^{2} \mathrm{~A}$ joggyakorlat-elemző csoport vizsgálati tárgyköre Az ingatlan-nyilvántartási perek gyakorlata címen meghatározva elsősorban a közigazgatási ügyszakban elbírált ingatlan-nyilvántartási perek vizsgálata volt. Mindemellett az elemzés kitér egyes polgári jogi kérdésekre is, különösen a törlési, kiigazítási, a végrehajtási igényperek és a társasházakkal összefüggő perek ítélkezési gyakorlatára, de a vizsgálati tárgykörhöz kapcsolódó polgári jogi, dologi jogi kérdéseket alapvetően nem kutatta.

A jelen dolgozat vizsgálatának tárgya a joggyakorlat-elemző csoport munkájához képest egyrészt szükebb körü, másrészt abban alapvetően polgári jogi, dologi jogi szempontú elemzések kapnak hangsúlyos szerepet. A megközelítés eltéréséböl is eredően a tanulmány a joggyakorlat-elemző csoport által nem tárgyalt szempontokat is érint ( $\mathrm{pl}$. a végrehajtási igényper kapcsán a vételárnak megfelelő összeg kiutalásának elemzése, a zálogjogosultakra vonatkozó speciális szabályok), továbbá elsődlegesen a polgári jogi vizsgálódás tárgykörében hangsúlyos olyan központi kérdéseket is érint, mint a nem tulajdonostól való szerzés lehetősége.

A téma részletesebb elemzését megelőzően elengedhetetlennek tartottam az ingatlanra vonatkozó szerzésmódok körében hangsúlyosabban kitérni azon több évtizedes múltú vitára, hogy vajon az ingatlan tulajdonjogának árverésen történő megszerzése eredeti vagy származékos szerzésmódnak minősül-e.

\section{Eredeti és származékos szerzésmód}

Az eredeti és származékos szerzésmód fogalmát a tételes anyagi jog nem tartalmazza, az elhatárolás azonban valamennyi, a tulajdonjog szerzésével kapcsolatos jogirodalom alapvető részét képezi. Ehhez képest a jogirodalomban némileg meglepő módon nem volt és nincs egységes álláspont arra nézve, hogy az egyes, a Ptk. által nevesített tulajdonszerzési módok ténylegesen besorolhatók-e és melyik kategóriába, ami azért okoz bizonytalanságot, mert az egyes szerzési módok kapcsán viszont szinte megkerülhetetlen az erre való hivatkozás. Lenkovics Barnabás egyenesen úgy fogalmaz a régi Ptk.-hoz füzött miniszteri indokolás kapcsán, hogy „az elhatárolást nem csak a Ptk., de a miniszteri indokolás sem tartalmazza, itteni és későbbi ezekre történő utalásai alapján azonban azt mondhatjuk, hogy mintegy adottnak, köztudottnak (triviálisnak) tekinti". ${ }^{3}$

Témám szempontjából kizárólag a hatósági határozat és hatósági árverés útján szerzett tulajdont emelem ki, mellyel kapcsolatban a fenti elhatárolás körében a leg-

2 Az ingatlan-nyilvántartási joggyakorlat-elemző csoport összefoglaló véleménye. Kúria, Budapest, 2016. 06. 13., http://www.kuria-birosag.hu/sites/default/files/joggyak/az_ingatlan-nyilvantartasi_joggyakorlat-elemzo_ csoport_osszefoglalo_velemenye_1.pdf (2017. 09. 09.).

3 Lenkovics Barnabás: A tulajdonszerzési módok eredeti illetve származékos jellege. Polgári Jogi Kodifikáció, 2003/3, 14-29., http://ptk2013.hu/polgari-jogi-kodifikacio/lenkovics-barnabas-a-tulajdonszerzes-modokeredeti-illetve-szarmazekos-jellege-pjk-20033-14-29-o/483 (2017. 09. 17.) . 
elterjedtebb és köztudott álláspont a régi Ptk. alkalmazása körében is az volt, hogy a tulajdon megszerzése eredeti szerzésmódon történik. ${ }^{4}$ Emellett egyes vélemények szerint az eredeti szerzésmód kizárólag az ingó dolgok megszerzése esetében valósul meg, míg az ingatlanok árverésen való megszerzése nem eredeti szerzésmódon történik. ${ }^{5}$ Más felfogás szerint valójában nem beszélhetünk tiszta rendszerről, és egyes szerzésmódok, köztük az ingatlannak - hatósági árverés útján való - megszerzése nem sorolhatók be tisztán a fenti kategóriák egyikébe sem. ${ }^{6}$

$A z$ eredeti és származékos tulajdonszerzési mód meghatározása körében sincs egységesen elfogadott álláspont. Amiben a témával foglalkozó szerzők nagyjából egyetértenek, az alábbiakban foglalható össze: „Eredeti szerzésmód esetén a tulajdonszerzés a korábbi tulajdontól függetlenül, az előző tulajdonos tulajdonjogára tekintet nélkül keletkezik, míg származékos tulajdonszerzés esetén (melynek legalapvetőbb módja az átruházáson alapuló tulajdonszerzés) a megszerzett tulajdonjog a korábbi tulajdonjogon alapszik, melyhez szorosan kapcsolódó elvként tapad a »nemo plus iuris« elve, vagyis mind az átruházó személye (nem tulajdonostól nem lehet szerezni), mind az átruházott tulajdonjogviszony tartalma (nem lehet más tartalommal szerezni) meghatározó."7 Az ingatlan-nyilvántartási joggyakorlat-elemző csoport összefoglaló véleménye lényegét tekintve azonos tartalommal definiálja az eredeti és származékos tulajdonszerzést. ${ }^{8}$

Az elhatárolási kérdés gyakorlati jelentőséget azáltal nyer, hogy az a nem tulajdonostól való tulajdonszerzés kérdéskörét érinti. A korábban hatályos Ptk. ${ }^{9} 120$. $\S$ (1) bekezdése tartalmazza az árverés útján történő tulajdonszerzés szabályait. Ennek alapján, aki a dolgot hatósági határozat vagy árverés útján jóhiszeműen szerzi meg, tulajdonossá válik, tekintet nélkül arra, hogy korábban ki volt a tulajdonos. Ez a rendelkezés ingatlan árverésére nem vonatkozik.

Ebből kifolyólag a kommentárokban megjelenő állásfoglalások szerint „a Ptk. 120. §-ából nem lehet azt a következtetést levonni, hogy ingatlannak árverésen való megszerzése eredeti jogszerzés lenne, hiszen a tulajdonszerzés nyilvánvalóan nem lehet független a korábbi tulajdonos személyétöl, ${ }^{10}[$...] ingatlan tulajdonjogát ugyanis - a törvény kizáró szabálya értelmében - árverésen nem tulajdonostól még jóhiszemüség mellett sem lehet megszerezni."11

4 Lásd Ptk. 120. §; VILÁGHY Miklós-EöRSI Gyula: Magyar polgári jog I. kötet. Tankönyvkiadó, Budapest, 1962 , 297; MenYhÁrd Attila: Dologi jog. ELTE Eötvös Kiadó, Budapest, 2014.

5 Eörsi Gyula-Gellért György (szerk.): A Polgári Törvénykönyv magyarázata 1. Közgazdasági és Jogi Könyvkiadó, Budapest, 1981, 553-554; Gellért György (szerk.): A Polgári Törvénykönyv magyarázata 1. Közgazdasági és Jogi Könyvkiadó, Budapest, 1995, 321.

6 Vesd össze LÉGRÁDI Gergely: Az árverésről - gondolatok egy Janus-arcú szerzésmódról. Polgári Jogi Kodifikáció, 2003/1, 9-18, http://ptk2013.hu/polgari-jogi-kodifikacio/dr-legradi-gergely-az-arveresrol-gondolatok-egyjanus-arcu-szerzesmodrol-pjk-20031-9-18-0/463 (2017. 09. 09.); KIRÁLY András: Ingatlan-nyilvántartás igénybevétele a bírósági végrehajtás során. Jogi Fórum, 2013. április 4., http://www.jogiforum.hu/publikaciok/503 (2017. 10. 01.)

7 HIDVÉGINÉ ERDÉLYI Erika: Ingatlannyilvántartás 2., 2. Általános dologi jogi alapvetés, http://www.tankonyvtar. hu/hu/tartalom/tamop425/0027 INY2/ch01s06.html (2017. 09. 17.).

8 Az ingatlan-nyilvántartási joggyakorlat-elemző csoport összefoglaló véleménye, i. m. 74.

9 1959. évi IV. törvény a Polgári Törvénykönyvröl (a továbbiakban: régi Ptk.).

10 Gellért György (szerk.): Ptk. Magyarázat. KJK-Kerszöv, Budapest, 1999, 334. Idézi LÉGRÁdI: i. m.

11 Pongrácz Eszter (szerk.): Kommentár a Polgári Törvénykönyvröl szóló 1959. évi IV. törvényhez. Complex Jogtár, KJK-Kerszöv, Budapest, 2002. 
A Legfelsőbb Bíróság, illetve a Kúria esetében azonban a fentiekkel szemben eltérő értelmezésen alapuló gyakorlat alakult ki. Ennek kapcsán két eseti döntés emelendő ki, melyek közül a korábbi, BH 1997.400. eseti döntésben a bíróság arra a jogértelmezésre helyezkedett, hogy noha ,ingatlan tulajdonjogát nem tulajdonostól még árverésen sem lehet érvényesen megszerezni, az árverési vevő tulajdonjoga azonban mégsem az adóstól származik, hanem az árverésen mint végrehajtási kényszeraktuson alapszik, az árverési vevő tehát nem lesz az adós jogutóda, szerzése eredeti szerzés. Ezért az árverési vevő által megszerzett tulajdonjogot csak a Vht. 137. §-ában foglalt jogok terhelhetik."12

A Legfelsőbb Bíróság egy későbbi döntésében az ingatlan tulajdonjogának árverésen történő megszerzését egyfajta „speciális, garanciális feltételekhez kötött olyan szerzésmódnak tekinti, amely az eredeti szerzés sajátos változata". A bíróság egyúttal kimondta, hogy árverésen alapuló tulajdonszerzés ingatlan vonatkozásában is eredeti szerzés, mert bár az árverésen szerző tulajdonjoga az árverést szenvedő tulajdonjogára tekintettel keletkezik, azonban nem abból származik, hanem az árverésen mint állami kényszeraktuson alapul. $A$ jóhiszemű szerző az érvényes árverés eredményeként tulajdonossá válik. Tulajdonszerzése azonban nem feltétlen, illetve független a korábbi tulajdonostól, hiszen tulajdonjoga az adós tulajdonjogára tekintettel keletkezik. ${ }^{13}$

A jelenleg hatályos Ptk.-nak ${ }^{14}$ a hatósági határozattal vagy hatósági árverés útján való tulajdonszerzésre vonatkozó rendelkezései szakítottak a régi Ptk. ingatlanokra vonatkozó és sok vitára okot adó korábbi kizáró rendelkezésével, így jelenleg egységes az ingókra és ingatlanokra vonatkozó szabályozás, egyúttal abból egyértelművé válik, hogy az ingatlan tulajdonjogának hatósági árverés útján történő megszerzése eredeti szerzésmód. A jelenleg hatályos Ptk. 5:41. § (1) bekezdése alapján, aki a dolgot hatósági határozat vagy hatósági árverés útján jóhiszeműen szerzi meg, tulajdonossá válik, tekintet nélkül arra, hogy korábban ki volt a tulajdonos.

Az új Ptk.-hoz füzött miniszteri indokolás is immár egyértelműen foglalkozik a kérdéssel, és ezzel kapcsolatban az alábbiakat tartalmazza. „A hatósági határozattal és hatósági árverésen való tulajdonszerzés a tulajdonjog megszerzésének eredeti módja. Aki árverésen vásárol, vagy hatósági határozattal szerzi meg valamely dolog tulajdonjogát, hatóság közremüködésével, eredeti jogcímen szerez. Ezt részben forgalomvédelmi szempontok támasztják alá, részben pedig - hatósági határozattal való szerzés esetén - az indokolja, hogy a szabályozás igyekszik kerülni azt, hogy a dologra vonatkozó korábbi tulajdonjog vizsgálata a tulajdonszerzésre vonatkozó hatósági határozat közvetett felülvizsgálatát jelenthesse."

Véleményem szerint a régi Ptk. 120. § (1) bekezdése az ingatlanokra nézve nem a nem tulajdonostól való szerzés lehetőségét zárta ki, pusztán amíg az ingók vonatkozásában a jóhiszemü árverési vevő feltétlen tulajdonszerzésére e rendelkezés nem hagyott kétséget, addig az ingatlanok vonatkozásában az egyéb alkalmazandó jogszabályok figyelembevétele mellett szükséges az árverési vevő tulajdon-

$12 \mathrm{BH} 1997.400$.

$13 \mathrm{BH} 2001.231$.

14 2013. évi V. törvény a Polgári Törvénykönyvröl (a továbbiakban: Ptk. vagy új Ptk.), 5:41. §. 
szerzésének bekövetkezését vizsgálni. Ingatlanra vonatkozóan nem tulajdonostól való „szerzés” kérdése gyakorlatilag két esetkörben merül fel. Az egyik az ingatlan-nyilvántartáson kívül bekövetkezö tulajdonszerzés esetkörében (pl. elbirtoklás, ráépítés), vagyis amikor a közhiteles ingatlan-nyilvántartás tartalmával szemben a valóságos tulajdoni állapot alapján a jogosult személye eltérő. A másik pedig az érvénytelen bejegyzésen alapuló tulajdonszerzés, vagyis tipikusan azok az esetek, amikor az ingatlan-nyilvántartásba bejegyzett tulajdonos vagy elődje tulajdonjogának bejegyzése érvénytelen jogügyleten alapul. Gyakorlatilag mindkét esetkörben bekövetkezhet az árverési vevő hatósági határozaton alapuló tulajdonszerzése olyankor is, ha az ingatlan-nyilvántartásba tulajdonosként bejegyzett adós az ingatlannak nem volt tulajdonosa. Jelen tanulmány részben ennek feltárását célozza, de ehhez mindenekelőtt ki kell térni olyan alapvető jogintézmények tárgyalására, melyek nélkül nem lehetséges teljes és világos képet alkotni. Két jogintézmény köré szerveződik a kutatási téma, ezek a végrehajtási igényper és a törlési per.

\section{A végrehajtási jog ingatlan-nyilvántartási bejegyzése}

\subsection{Az adós tulajdonában áló ingatlan lefoglalása, a végrehajtási jog bejegyzése}

Az adós ingatlanának végrehajtás alá vonása az ingatlan lefoglalásával történik. Az ingatlan lefoglalása a végrehajtási jog ingatlan-nyilvántartási bejegyzésével valósul meg. ${ }^{15}$ Tekintettel arra, hogy az ingatlan foglalása a közhiteles ingatlan-nyilvántartás adatai alapján, a végrehajtási jog ingatlan-nyilvántartásba való bejegyzésével valósul meg, ezért értelemszerủen nem vet fel problémát, hogy a foglalás, azaz a végrehajtási jog bejegyzése minden esetben az ingatlan-nyilvántartásba bejegyzett adós mint tulajdonos tulajdonára, tulajdoni hányadára történik meg. Amennyiben a végrehajtási jog bejegyzése iránti végrehajtói megkeresés földhivatali iktatásának időpontjában az ingatlan már nem az adós tulajdonát képezi, úgy az ilyen kérelmet a földhivatal elutasítja az Inytv. 49. § (1) bekezdése alapján.

Az ingatlan lefoglalásának részletes szabályait alapvetően a Vht. tartalmazza. $A$ végrehajtó az ingatlan lefoglalása végett megkeresi az ingatlanügyi hatóságot, hogy a végrehajtási jogot jegyezze be az ingatlan-nyilvántartásba.

$A z$ ingatlanügyi hatóság a végrehajtási jog bejegyzését - ideértve a megelőző beadványokat is - a végrehajtási költségként megelölegezett igazgatási szolgáltatási díj megfizetését követően soron kívül intézi el. ${ }^{16}$

A végrehajtó megkeresése hatósági határozat, mely az ingatlan-nyilvántartási eljárás megindításának alapját képezi. Maga a megkeresés tehát a végrehajtó olyan hatósági intézkedése, amely a bejegyzés alapjául szolgál, ahhoz nem szükséges a végrehajtható okirat csatolása. „A földhivatal a bejegyzést önmagában a végrehajtó megkeresése alapján tartozik teljesiteni, és nincs hatásköre a megkeresés alapjául

\footnotetext{
15 Vht. 138. § (2) bek.

16 Vht. 138. § (3) bek.
} 
szolgáló okiratok vizsgálatára. A végrehajtó esetleges téves intézkedésével szemben a Vht. 217. § (2) bekezdése értelmében végrehajtási kifogásnak van helye."17

A fentiekkel összefüggésben kiemelendő továbbá, hogy a végrehajtási jog bejegyzésének soron kívül történő intézése nem jelent az ingatlan-nyilvántartási rangsortól eltérö ügyintézést, melynek alapján a kérelmeket, illetőleg megkereséseket az iktatás rangsorában kell elintézni. ${ }^{18}$

\subsection{A végrehajtási igényper}

Amennyiben az ingatlan lefoglalása, vagyis a végrehajtási jog bejegyzése megtörténik, ezzel együtt megnyílik az út az ingatlan árverési értékesítéséhez vezető folyamatban. A folyamat nem visszafordíthatatlan, az ingatlan árverési értékesítését az adós az önkéntes teljesítéssel továbbra is elháríthatja, illetőleg amennyiben valaki az ily módon lefoglalt vagyontárgyra tulajdonjoga vagy más olyan joga alapján tart igényt, amely a végrehajtási értékesitésnek akadálya, úgy erre hivatkozással neki kell a vagyontárgy foglalás alóli feloldása iránt végrehajtási igénypert indítani a végrehajtást kérő ellen. ${ }^{19}$

$A$ régi $P p$. szabályaihoz képest az új $P p$. nem hozott lényeges tartalmi változást az igényper kapcsán, a legfontosabb módosításként az alábbiak említendők. Az új Pp. egyértelmüsíti, hogy igénypernek nemcsak a bírósági végrehajtásban, hanem a közigazgatási, illetve adóvégrehajtásban lefoglalt vagyontárgy vonatkozásában is helye van. $A z$ ingatlanigényperben a régi $\mathrm{Pp}$. szabályaival szemben az új $\mathrm{Pp}$. az ingatlan fekvése szerinti járásbíróság kizárólagos illetékességét állapítja meg.

Amennyiben az, aki egyébként erre jogosult lenne, az igénykeresetet nem terjeszti elő, illetőleg esetleg jogsérelmét más, erre alkalmatlan eszközzel próbálja elhárítani (például végrehajtási kifogással), úgy végső soron ennek kockázatát maga fogja viselni, hiszen ebben az esetben az adós tulajdonaként lefoglalt ingatlan árverési értékesítése megtörténik. ${ }^{20}$

A végrehajtási igényper alapja a tulajdonjogon kívül csak olyan jog lehet, amely a végrehajtás során történő értékesítésnek akadálya, amelyre nézve a Pp. még példálózó felsorolást sem tartalmaz, ezért esetenként kell eldönteni, hogy adott jog állítása és alátámasztása mellett az a végrehajtáson való értékesítést akadályozza-e.

A lefoglalt ingatlanra tulajdonjoga alapján kizárólag az támaszthat igényt, aki az ingatlan tulajdonjogát - a végrehajtási jog bejegyzését megelőzően - ingatlannyilvántartáson kívül szerezte meg (pl. elbirtoklás, ráépítés). Ugyanis figyelemmel arra, hogy a legtöbb szerzésmód esetén az ingatlanra vonatkozóan a tulajdonjog annak ingatlan-nyilvántartási bejegyzésével keletkezik (maga az ingatlan-nyilvántartási bejegyzés konstitutív, jogkeletkeztető hatályú), ezeknél a szerzésmódoknál

17 Veszprém Megyei Bíróság 8.K.21.204/2004/5; LESCH Norbert: A végrehajtási eljárás ingatlan-nyilvántartási vonatkozásai. Res Immobiles, 2011/3-4., http://www.resimmobiles.hu/docs/04_lesch_vegrehajtasi_eljaras. pdf (2017. 09. 09.).

18 1997. évi CXLI. törvény az ingatlan-nyilvántartásról (a továbbiakban: Inytv.) 7. § (1) bek., 44. § (1) bek.

19 Régi Pp. 371. § (1) bek., új Pp. 538. § (1) bek.

20 Vesd össze: Kúria Pfv.I.20.518/2014/8. ítélete; Fővárosi Ítélőtábla 6.Pf.20.186/2009/3. számú ítélete. 
nem beszélhetünk arról, hogy az igénylő a tulajdonjoga alapján tart igényt az adós tulajdonaként lefoglalt ingatlan feloldására. Ebben az esetben arról van szó, hogy az igénylő a jogszabályban előírt „más olyan joga” alapján kérheti a vagyontárgy foglalás alóli feloldását, amely a végrehajtási értékesítésnek akadálya. Az ingatlanszerzésre és az ingatlan-nyilvántartási bejegyzés konstitutív hatályára a legtipikusabb eset az átruházáson alapuló tulajdonszerzés, melynek körében a régi Ptk. 117. § (3) bekezdése szerint ingatlan tulajdonjogának átruházásához az erre irányuló szerződésen vagy más jogcímen felül a tulajdonosváltozásnak az ingatlan-nyilvántartásba való bejegyzése is szükséges. Ezzel tartalmilag egyező rendelkezést tartalmaz a Ptk. 5:38. $\S(2)$ bekezdése is.

A lefoglalt ingatlanra támasztott jogos végrehajtási igényperben ilyenkor tehát valójában olyan kötelmi jogi igény az igénykereset alapja, amely egyúttal alkalmas kell, hogy legyen az igényper kínálta jogvédelemre azáltal, hogy az akadálya az ingatlan végrehajtási eljárás keretében történő árverési értékesítésének. Nyilvánvalóan nem alkalmas például a végrehajtási értékesítés megakadályozására a végrehajtási jog bejegyzését követően megkötött adásvételi szerződésre alapított igénykereset. Fontos hangsúlyozni, hogy a bírói gyakorlat szerint az egyéb jog alapján indított eredményes igényper alapját érvényes és hatályos szerződésen alapuló kötelmi igény alapozhatja meg, amely ezáltal alkalmas arra, hogy a vagyontárgy végrehajtási értékesítését akadályozza. Ennek kapcsán az alperesként perben álló végrehajtást kérő - viszontkereset előterjesztése nélkül, mert annak a végrehajtási igényperben nincs helye ${ }^{21}$ - kifogásként a felperes keresete elutasítása végett adott esetben hivatkozhat a felperes jogszerzésének relatív hatálytalanságára is.

Amennyiben a bíróság az igénykeresetnek helyt ad, úgy a végrehajtás alá vont ingatlant a foglalás alól feloldja, tehát ebben az esetben nem kerül sor az ingatlan árverési értékesítésére. Ez azonban csak a fő szabály, mert előfordulhat, hogy a jogerős ítélet meghozataláig az igényelt vagyontárgyat már értékesítették. Ekkor az igénylő magára a vagyontárgyra már alappal nem támaszthat igényt, hanem a pernyertessége esetén részére a vételárnak megfelelö összeget kell kiutalni. ${ }^{22} \mathrm{Ez}$ az a pont, ahol elsőként szükséges visszakanyarodni a régi Ptk. 120. § (1) bekezdésében foglaltakhoz, és ennek kapcsán az ingatlanokra vonatkozó eredeti szerzésmóddal, valamint a jogszabályi rendelkezés értelmezésével kapcsolatos álláspontokhoz. Amennyiben ugyanis a jogalkotó kategorikusan ki akarta volna zárni az árverési vevő tulajdonszerzését olyan ingatlan tekintetében, amelynek nem az adós (árverést szenvedő) a valódi tulajdonosa, akkor nyilvánvalóan nem rendelkezett volna az alapos tulajdoni igénykeresettel fellépő jogosult vonatkozásában akként, hogy a már értékesített vagyontárgy vonatkozásában pernyertessége ellenére is csakis a vételár megfelelő részének kiutalására jogosult. Következésképp kétségtelen, hogy a vagyontárgy tulajdonjogát ilyen esetben az árverési vevő valójában arra tekintet nélkül szerzi meg, hogy korábban nem az adós (árverést szenvedő) volt annak a tulajdonosa. Noha az igényperben az árverési vevő nem vesz részt félként, hiszen azt az adósnak a végrehajtást kérővel szemben kell megindítania, a fenti megállapítás

21 Régi Pp. 375. §, új Pp. 543. § (3) bek.

22 Régi Pp. 377. § (1)-(2) bek., új Pp. 544. § (1) bek. 
azért tűnik nyilvánvalónak, mert amennyiben az alapos igénylő az elárverezett dolog árverési vételárának megfelelö összeget megkapta (ami nem feltétlenül azonos a dolog reális értékével, mindenesetre a jogszabály alapján ez a dolog helyébe lépett értéknek minősül), úgy nehezen elképzelhető, hogy ezen túl még az árverésen szerzővel szemben eredményes tulajdoni igénnyel is fellépjen.

Mi történik azonban akkor, ha például az ingatlan-nyilvántartáson kívül szerzett tulajdonjogát állító személy az adós tulajdonaként nyilvántartott ingatlan lefoglalása (a végrehajtási jog bejegyzése), valamint az ingatlannak az árverésen történő értékesítését követő vételár felosztása és a végrehajtást kérő hitelező(k) részére történt kiutalása közötti időszakban bármilyen oknál fogva elmulasztja az igényper megindítását. Utóbb felléphet-e az árverési vevővel szemben arra is hivatkozással, hogy az ő tulajdoni igénye a régi Ptk. 115. § (1) bekezdése (új Ptk. 5:35. §) alapján el nem évülő igény?

\subsubsection{Meddig indítható igényper?}

Erre a kérdésre rögtön kétfajta válasz adható. Egyrészt, amennyiben a keresetindítási határidő szempontjából keressük a választ a kérdésre, úgy elméletileg bármeddig, figyelemmel arra, hogy a régi Pp. 371. § (1) bekezdése, illetőleg az új Pp. 538. § (1) bekezdése alapján indítható végrehajtási igényperre a jogszabály nem tartalmaz keresetindítási határidőt, ezért az ilyen keresetlevelet a régi $\mathrm{Pp} .130$. $§(1)$ bekezdésének h) pontja alapján semmikképpen nem lehet idézés kibocsátása nélkül elutasítani, illetőleg az új Pp. 176. § (1) bekezdésének i) pontja alapján visszautasítani, azt érdemben kell elbírálni. Ugyanakkor eredményes igényper indítására még sincs bármeddig lehetőség, mert a Pp. idevonatkozó szabályai az igényérvényesítés lehetőségét szigorú keretek közé szorítják.

Noha az alább ismertetett, a Kúria Pfv.I.20.885/2012/6. számú eseti döntése ingóra vonatkozó igényperben született, azonban a döntés alapjául szolgáló jogszabályi rendelkezések és a jogkövetkeztetés ugyanúgy irányadó ingatlanok esetére is. A döntés külön érdekessége, hogy a felperes igénykeresete érdemben az igénye késedelmes előterjesztése miatt, vagyis annak elkésettsége okán lett elutasítva. A döntés jogalapját a régi Pp. már idézett 371 . $§(1)$ bekezdése mellett a régi Pp. 377. § (1) és (2) bekezdése képezi. Utóbbi rendelkezések szerint, ha a bíróság az igénykeresetnek helyt ad, az igényelt vagyontárgyat feloldja a foglalás alól. Ha a vagyontárgyat már értékesítették, a pernyertes felperes részére a vételárnak megfelelő összeget kell kiutalni. A döntés indokolása szerint a Pp. 371. § (1) bekezdésének megfelelő igénykereset alapján igényper megindítására a jogszabály nem állapít meg határidőt. „Figyelemmel azonban arra, hogy az igénykereset - annak lényegét tekintve - a lefoglalt vagyontárgy foglalás alól történő feloldását teszi lehetővé, s ezáltal annak végrehajtási értékesítését akadályozza meg, eredményes igénykereset csupán addig az időpontig nyújtható be, amíg erre lehetőség van, azaz a foglalás fennáll. A Pp. 377. § (2) bekezdése az időben - a foglalás fennállása alatt - benyújtott igénykereset elbírálásának lehetőségét hosszabbítja meg abban az esetben, amikor a lefoglalt vagyontárgy értékesítése időközben megtörtént, de az értékesítésből befolyt vételár még rendelkezésre áll. A Pp. 377. § (2) bekezdését 
a bírói gyakorlat kiterjesztően értelmezi: eszerint nemcsak a bírói döntés, hanem az igénykereset benyújtására is lehetőség nyílik mindaddig, amíg a pert tárgyaló bíróság az értékesítésböl befolyt összeg kiutalásáról intézkedni tud. Abban az esetben, ha az igénykereset benyújtása időben történt (tehát amikor a foglalás még fennállt, vagy amikor a vételár még kiutalható volt), azonban a bírósági határozat meghozatalának időpontjára a végrehajtás során befolyt összeget már a végrehajtást kérő részére kifizették, a bíróság a pervesztes alperest (a végrehajtást kérőt) annak az összegnek a megfizetésére kötelezheti, amely a vagyontárgy értékesítéséből hozzá befolyt." Ez az a kivételes eset, amikor a bíróság nem a végrehajtói letéti számlára befolyt összeg felperesnek való kiutalásáról rendelkezik, hanem a végrehajtást kérő alperest marasztalja a neki már kiutalt összeg megfizetésére.

„Az igényper lényegéből ered ugyanakkor az a következmény is, hogy az igénykereset nem vezethet sikerre, ha a benyújtása a lefoglalt vagyontárgy végrehajtási értékesítéséből befolyt összeg felosztását követően, a végrehajtási eljárás befejeződése után történt, hiszen ekkor már nincsen lehetőség sem a foglalás feloldására, sem a letétben kezelt vételár kifizetésére."23

Visszautalva arra, hogy az eseti döntés tárgyát ingó vagyontárgyra vonatkozó igény képezte, ezért hangsúlyozandó, hogy kifejezetten ingóságokra utalva a Kúria megjegyezte, hogy a gépjármű tulajdonjogát hatósági árverésen megszerzőt a Ptk. 120. $§(1)$ bekezdése védi, ha jóhiszemúsége megállapítható.

Figyelemmel arra, hogy az új Pp. az igényper megindítására, a kereset elbírálására vonatkozóan nem tartalmaz a korábbitól eltérő szabályozást, az ingó vonatkozásában a jóhiszemü árverési vevő a dolog tulajdonjogát a Vht. 127. § (1) bekezdése szerint a vételár kifizetésével, illetőleg a jelenleg hatályos Ptk. 5:41. § (3) bekezdése szerint a dolog birtokának - a végrehajtó általi - átruházásával megszerzi, és vele szemben a korábban hatályos Ptk. 120. § (1) bekezdése alapján tulajdoni igénnyel eredményesen fellépni nem lehet, ezért kimondható, hogy az ingóra a jóhiszemü árverési vevő tulajdonszerzése feltétlen és végleges. Az ingatlanok vonatkozásában azonban a szabályozás nem ilyen egyértelmü, az részletesebb elemzést igényel. Alapvető kérdés, hogy ingatlanok esetén a jóhiszemü árverési vevő tulajdonszerzésének bekövetkezése feltételes-e (azaz vele szemben utóbb eredményes tulajdoni igény támasztható-e), és ha igen, úgy a tulajdonszerzés mikor tekinthető véglegesnek. Korábban már kitértem arra, hogy abban az esetben, ha a tulajdoni igénnyel fellépő már a végrehajtást kérővel szemben megindított igényperben érvényesítette a dologra vonatkozó igényét a végrehajtási eljárás azon szakaszában, amikor a dolgot még eredményesen fel lehet oldani a foglalás alól, úgy az árverés el sem jut abba a szakaszba, hogy arra nézve árverési vevő tulajdont szerezzen. Amikor a dolgot ugyan már annak értékesítése miatt nem lehet feloldani a foglalás alól, de annak az árverésen befolyt vételára még kiutalható, úgy az eredményes tulajdoni, illetve a tulajdonjog megszerzésére irányuló kötelmi igénylő a befolyt vételárnak megfelelő összeget kapja meg. Álláspontom szerint utóbbi esetben az ily módon kiutalt összeg a dolog helyébe lépett érték, ami kizárja, hogy ezt követően az igénylő a jóhiszemü árverési vevőtől a dolog tulajdonjogát követelje. Abban az esetben ugyanis, ha a

23 Kúria Pfv.l.20.885/2012/6. 
dolog megfelelő vételárának kiutalása, mint a dolog helyébe lépett érték nem az igénylő tulajdonjogviszonya megszűnése „ellenértékének” lenne betudható, úgy a jogszabálynak rendelkezést kellene tartalmaznia arra nézve, hogy az igénylö az így kapott vételár felajánlása mellett a dolog kiadását követelhesse az árverési vevötől. Ugyanakkor erre nézve rendelkezés nincs, ezért véleményem szerint ingatlan esetében a jóhiszemú árverési vevő feltétlen tulajdonszerzésének bekövetkezése a fentiek alapján - a Ptk. 120. § (1) bekezdésétől függetlenül - szintén levezethető. Mindemellett abból eredően, hogy az árverési vevő tulajdonjogának bejegyzését és a befolyt vételár felosztását követően végrehajtási igényper eredményesen már nem indítható, így utóbbi esetben még az egyébként alapos tulajdoni igénnyel rendelkező felperes is viselni köteles a késedelmes igényérvényesítés jogkövetkezményeként azt, hogy ingatlan-nyilvántartáson kívüli jogát az árverési vevővel szemben nem érvényesítheti, így a nemo plus iuris elve és a nem tulajdonostól való szerzés tilalma ebben az esetben csak látszólagos, illetőleg ezen elvek áttörése még ingatlanok esetén is bekövetkezik. [Egyébként az igénykereset előterjesztésének ilyen „,időbeli korlátja” teljesen összhangban van az Inytv. 5. § (4) bekezdésével, amiről az alábbiakban külön is lesz szó.]

\subsubsection{Az igénykereset elmulasztása, illetve késedelmes előterjesztése hogyan hat az árverési vevő jogállására?}

A korábban hatályos Inytv. 5. § (4) bekezdése kifejezetten kimondta, hogy az ingatlan-nyilvántartáson kívüli jogot szerzők nem érvényesíthetik megszerzett jogukat az ingatlan-nyilvántartásba bejegyzett, jóhiszemű jogszerzővel szemben.

A jelenleg hatályos Ptk. 5:175. §-a a fentiekkel tartalmilag egyezően az ingatlan-nyilvántartáson kívül jogot szerző jogállása körében kimondja, hogy (1) az ingatlan-nyilvántartáson kívül jogot szerző személy vagy az ingatlan-nyilvántartásba feljegyezhető tény jogosultja a szerzett jogát, illetve a feljegyezhető tényt nem érvényesítheti az ingatlan-nyilvántartásba bejegyzett vagy az őt bejegyzési igénnyel rangsorban megelőző, jóhiszemű szerzővel szemben. A (2) bekezdés továbbá azt is kimondja, hogy az ingatlan-nyilvántartásba be nem jegyzett jogot és fel nem jegyzett tényt a jóhiszemű és ellenérték fejében jogot szerző, valamint a bejegyzési igénnyel rangsorban elörébb álló, jóhiszemű jogszerzővel szemben nem lehet érvényesíteni. A jóhiszemű szerző jogvédelme az ingatlan-nyilvántartási állapot függő jogi helyzetére utaló tény feljegyzése esetére nem terjed ki.

A fentiek alapján abban az esetben, ha az igénylö (ingatlan-nyilvántartáson kívüli tulajdoni igénnyel vagy kötelmi igényen alapuló, tulajdonjog megszerzése iránti igénnyel rendelkező) személy elmulasztja a végrehajtást kérővel szemben előterjeszteni a végrehajtási igénykeresetet, illetőleg azt a fenti módon késedelmesen terjeszti elő, úgy igényét a már árverésen értékesített ingatlan vonatkozásában a jóhiszemú árverési vevővel szemben annak tulajdonjoga megszerzését (bejegyzését) követően nem érvényesítheti. „Mivel az ingatlan-nyilvántartáson kívüli tulajdonossal szemben (aki elmulasztotta jogának bejegyzését) az árverési vevő abszolút (azonnali és teljes) védelmet érdemel és élvez, biztos lehet abban, hogy az ingatlan-nyil- 
vántartásban nem szereplö és így számára felismerhetetlen személyek nem tehetik vitássá jogszerzését."24

\subsection{A végrehajtási jog bejegyzését követően az ingatlanra bejegyezhető jogok}

Az ingófoglalással szemben, melyre nézve a Vht. 104. § (3) bekezdése alapján a foglalás ténye elidegenítési és terhelési tilalmat keletkeztet, az ingatlan lefoglalásával nem keletkezik elidegenítési és terhelési tilalom, azaz a végrehajtási jog bejegyzését követően az ingatlan továbbra is forgalomképes, harmadik személyre átruházható. A Vht. 138. § (6) bekezdése alapján azonban a lefoglalt ingatlanra vonatkozólag jogot csak azzal a feltétellel lehet szerezni, hogy az a végrehajtást kérő jogát nem sérti, és a végrehajtás célját nem hiúsítja meg.

Előfordulhat, hogy a végrehajtási jog bejegyzését követően az adós eladja, a végrehajtási eljárás keretében pedig elárverezik az ingatlant. A gyakorlatban e kapcsán az a jogértelmezési probléma vetődött fel, hogy a végrehajtási jog bejegyzésével az adós tulajdonaként lefoglalt, ám ezt követően az adós részéről harmadik személyre átruházott - ezért immár nem az adós tulajdonaként nyilvántartott - ingatlanra vonatkozóan az árverési vevő javára az ingatlanügyi hatóság a tulajdonjogot nem jegyezte be az ingatlan-nyilvántartásba az Inytv. 49. § (1) bekezdésére hivatkozással. Az Inytv. 49. § (1) bekezdése szerint ugyanis az ingatlan-nyilvántartásba jog és tény csak azzal szemben jegyezhető be, aki ott jogosultként már szerepel, vagy akit egyidejüleg jogosultként bejegyeznek.

Könnyü belátni, hogy a fenti gyakorlat szerinti jogértelmezés esetén a végrehajtási joggal terhelt ingatlan adós általi átruházása a végrehajtás célját meghiúsítaná, a Kúria Kfv.III.37.792/2012/7. számú eseti döntése (20/2014. számú közigazgatási elvi határozat) a jogszabályok közti látszólagos ellentmondást azonban már megnyugtatóan feloldotta. Ebben az eseti döntésben a Kúria kifejtette, hogy „az ellentmondás az Inytv. 49. § (1) bekezdése és a Vht. 138. § (6) bekezdése között valójában látszólagos, mert az utóbbi szabály speciális szabálynak tekinthető az Inytv. 49. § (1) bekezdéséhez képest, amely így megelőzi az Inytv. szabály alkalmazását” (lex specialis derogat legi generali).

A Kúria a döntésében kiemelte továbbá, hogy az Inytv. „3. § (3) bekezdése ugyanakkor azt az elöírást is adja, hogy e törvényben meghatározott egyes jogok és jogilag jelentős tények bejegyzése a későbbi jogszerző szerzését korlátozza, vagy feltételessé teszi. A Kúria álláspontja szerint a Vht. 138. §-ának (6) bekezdése értelmében ilyen jognak kell tekinteni a végrehajtási jogot is. [...] Ha az ingatlan-nyilvántartásba végrehajtási jog van bejegyezve, a bejegyzés ranghelyét követő időpontban adásvétellel szerzett tulajdonjog az árverési vevő tulajdonszerzéséhez képest csak feltételes lehet. Feltételes szerzésre tekintettel a szerző nem csak az árverést, hanem az időközben feltétellel bejegyzett joga megszünését is köteles türni, bármilyen egyéb

\footnotetext{
24 Az ingatlan-nyilvántartási joggyakorlat-elemző csoport összefoglaló véleménye, i. m., 90.
} 
igényét csak külön perben érvényesitheti." ${ }^{25}$ Kifejti továbbá, hogy az ingatlanügyi hatóság a szerzés feltételes jellegére tekintettel köteles az árverési vevő tulajdonjogát bejegyezni minden más eljárás megkívánása nélkül. $A$ Vht. 138. $§(6)$ bekezdése tehát nem az elidegenítést vagy a terhelést korlátozza, illetve tiltja meg, hanem az ilyen szerzéseket feltételhez köti. Ez a feltétel nem más, mint a végrehajtást kérő végrehajtási joga ne sérüljön, a végrehajtás célja (miszerint hogy a kötelezett teljesítse a kötelezettségét) ne hiúsuljon meg.

A Kúria fenti közigazgatási ügyben hozott határozatának jelentőségét nem lehet eléggé hangsúlyozni, már csak azért sem, mert az egy sor további, korábban bizonytalanságot okozó kérdést is megválaszol. Nincs szükség például arra, hogy a végrehajtást kérő a Vht. 39 . § (1) bekezdése alapján az adós személyében való változásra hivatkozással jogutódlás megállapítását kísérelje meg elérni a végrehajtást foganatosító bíróságnál, hiszen erre azért nincs lehetőség, mert az adós személye a végrehajtás alá vont ingatlan átruházásával nem változik meg, az új tulajdonos nem válik a végrehajtás alatt álló követelés kötelezettjévé, kizárólag kvázi dologi kötelezettként felel az ingatlannal. Nincs szükség ugyanakkor arra sem, hogy a végrehajtást kérő a végrehajtási joggal terhelt ingatlant megszerző tulajdonos ellen a vagyontárgyból való kielégítés türése iránt pert indítson és ezáltal vele szembeni is önálló végrehajtható okirathoz jusson. A végrehajtó az adós tulajdonaként lefoglalt ingatlant arra tekintet nélkül árverésre bocsáthatja, hogy annak ki az adott pillanatban bejegyzett tulajdonosa, aki pedig türni köteles, hogy az árverési vevő tulajdonjogának bejegyzésével egyidejüleg az ő - feltételesen szerzett - tulajdonjoga törlésre kerüljön.

Mindez továbbá azt is jelenti, hogy a végrehajtási jog bejegyzését követően az ingatlanügyi hatóság nem vizsgálja, nem is vizsgálhatja az ingatlanra valamely jog bejegyzése iránti kérelem kapcsán, hogy az sértheti-e a Vht. 138. § (6) bek. alapján a végrehajtás célját, illetőleg a végrehajtást kérő jogát, erre tekintet nélkül bármely jog bejegyezhető. Annak szerzésére továbbá, aki a végrehajtási joggal terhelt ingatlanra szerez az ingatlan-nyilvántartásba bejegyzett jogot, feltétel nélkül irányadó, hogy az ingatlan-nyilvántartás közhitelességének elvéböl fakadóan nem hivatkozhat arra, hogy a végrehajtást kérő javára a végrehajtási jognak az ingatlan-nyilvántartásba való bejegyzéséröl nem tudott.

Az adásvétel útján szerző fél oldaláról a végrehajtási igényper kapcsán a fentiek megítélésénél annak van jelentősége, hogy az adásvételi szerződést a végrehajtást kérő végrehajtási jogának ingatlan-nyilvántartásba való bejegyzése előtt kötötték-e meg, vagyis a tulajdonjog bejegyzése iránti kötelmi igénye korábban keletkezett-e, mint a végrehajtást kérő végrehajtási joga. ${ }^{26}$

A fentiek alapján összegzésképpen rögzítendő, hogy noha a lefoglalt ingatlannal az adós a végrehajtási jog bejegyzése után is rendelkezhet, azonban a Vht. 138. $\S(6)$ bekezdéséből következően az ingatlanra jogot szerző jogszerzése feltételes. Ennek megfelelően a végrehajtási jog bejegyzését követően megkötött adásvételi szerződés és bejegyzett tulajdonjoga ellenére a vevő igénypert nem indíthat, továbbá türni köteles az ingatlan elárverezését és a tulajdonjogának az ingatlan-

25 Kúria Kfv.III.37.792/2012/7. számú eseti döntése (20/2014. számú közigazgatási elvi határozat).

26 BDT 2001. 463. eseti döntés. 
nyilvántartásból való törlését, mert a végrehajtási jog bejegyzésének ranghelyét követő időpontban kötött adásvételi szerződésen alapuló tulajdonszerzés az árverési vevő tulajdonszerzéséhez képest csak feltételes lehet. A vevő a feltételes szerzésre tekintettel nemcsak az árverést köteles türni, hanem az időközben feltétellel bejegyzett tulajdonjoga megszúnését is, bármilyen egyéb igényét csak külön perben érvényesítheti. A feltételes szerzés miatt az ingatlanügyi hatóság az árverési vevő árverés címén való tulajdonjoga bejegyzését nem utasíthatja el azon a címen, hogy az ingatlannak már nem az adós az ingatlan-nyilvántartásba bejegyzett tulajdonosa.

\section{Törlési per és annak korlátai}

\subsection{Az adós érvénytelen bejegyzésen alapuló tulajdonjoga, perfeljegyzés az ingatlanra}

Előfordulhat, hogy az adós tulajdonaként nyilvántartott ingatlanra nem olyan személy támaszt igényt, aki a tulajdonjogát az adóstól mint átruházótól érvényes kötelmi szerződés alapján származtatja, illetőleg annak tulajdonára nem is valamely ingatlan-nyilvántartáson kívüli szerzésmódon támaszt igényt, hanem mint az ingatlan korábban bejegyzett tulajdonosa az adósra általa átruházott ingatlan vonatkozásában alapul szolgáló szerződés (jogügylet) érvénytelensége okán az eredeti állapot helyreállítása címén kéri az adós tulajdonjogának törlését és a saját tulajdonjoga visszajegyzését. Amennyiben ilyen érvénytelenség iránti per van folyamatban az adóssal szemben, ez nem képezi semmilyen akadályát annak, hogy az adós tulajdonaként nyilvántartott ingatlanra az adóssal szemben vezetett végrehajtás alapján az ingatlanra végrehajtási jog kerüljön bejegyzésre, még akkor sem, ha a felperes kérelmére, a bíróság előzetesen végrehajtható végzése alapján az ingatlanra perindítás ténye kerül feljegyzésre.

Az Inytv. 64. § (1) bekezdésének idevonatkozó pontjai alapján a bíróság az ügyfél kérelmére - előzetesen végrehajtható végzéssel - megkeresi az ingatlanügyi hatóságot a törlési és kiigazítási, illetőleg az ingatlan tulajdonjoga iránti per megindítása tényének feljegyzése iránt. Az Inytv. 65. § (1) bekezdése alapján a feljegyzett perben hozott határozaton alapuló változás bejegyzésével egyidejüleg törölni kell a perfeljegyzést és a függő hatállyal történt bejegyzéseket. Az Inytv. vhr. ${ }^{27}$ jelenleg hatályos 29. § (1) bekezdése szerint az Inytv. 64. §-ában meghatározott perek feljegyzését és a büntetőeljárás megindítása tényének feljegyzését (a továbbiakban együtt: perfeljegyzés) követően további jogokat - a jogszabályon, bírósági vagy hatósági határozaton alapuló, továbbá a törvény 16 . § e) és f) pontjában meghatározott jogok kivételével - csak a per, illetve a büntetőeljárás befejezésének eredményétől függő hatállyal lehet bejegyezni. A feljegyzésben erre utalni kell. A perfeljegyzést követően az ingatlan-nyilvántartásba bejegyzett végrehajtási jogon alapuló árverés esetén az árverési vevő a per, illetve a büntetőeljárás befejezésének eredményétől függő hatállyal szerzi meg az ingatlan tulajdonjogát. A feljegyzésben erre utalni kell.

27 109/1999. (XII. 29.) FVM rendelet az ingatlan-nyilvántartásról szóló 1997. évi CXLI. törvény végrehajtásáról. 
Figyelemmel arra, hogy a fenti hatályos rendelkezések alapján a perfeljegyzést követően az ingatlan-nyilvántartásba bejegyzett végrehajtási jogon alapuló árverésen az ingatlanra az árverési vevő egyértelmüen csak a per eredményétől függő hatállyal szerezheti meg az ingatlan tulajdonjogát, így ebben az esetben az árverési vevő tulajdonszerzése feltételes, hasonlóan ahhoz, mint az egyéb jogosultak feltételes szerzése a végrehajtási jog bejegyzését követöen.

„A közigazgatási bírói gyakorlat elvi tétele szerint a perfeljegyzéshez füződő joghatás kettős. Egyrészt e tény bejegyzését követően az ingatlanra jogot szerző személyek már nem jóhiszemüek. Másrészt a perben hozott itélet hatálya kiterjed mindenkire, aki a perfeljegyzés után szerzett további jogot, akkor is, ha a további jogszerzőt nem vonták perbe." ${ }^{28}$ Álláspontom szerint a perfeljegyzés nem zárja ki a jóhiszemüséget, két alapvető joghatás pedig az - a végrehajtási eljárásra vonatkozóan is -, hogy a perfeljegyzés függő hatálya folytán, annak ingatlan-nyilvántartási bejegyzését követően az ingatlanra jogot - így tulajdonjogot is - csak feltételesen lehet szerezni, és az, hogy a perben hozott ítélet hatálya perbevonásuk nélkül is kiterjed a további szerzőkre.

A perfeljegyzés által előidézett függő hatály alapján ugyanis [hasonlóan a végrehajtási jog Vht. 138. § (6) bekezdéséhez kapcsolódó függő hatályához] a földhivatal az ilyen feltételes tulajdonszerzést utóbb hivatalból köteles törölni az ingatlan-nyilvántartásból, amennyiben a per eredményeként a bírósági megkeresés az érvénytelen szerződés alapján az eredeti ingatlan-nyilvántartási jogosult tulajdonjogának visszajegyzésére irányul. Ebben az esetben ugyanis attól függetlenül, hogy a perfeljegyzést követően ki(k) az ingatlan tulajdonosaként bejegyzett személy(ek), a földhivatalnak minden esetben törölnie kell - az Inytv. 65. § (1) bekezdésének alkalmazása mellett - a perfeljegyzést követően szerzett jogosultakat. Mindez azt is jelenti ugyanakkor, hogy a perfeljegyzést követő szerzőkkel szemben nincs szükség arra, hogy a bíróság ítélete a tulajdonjoguk törlésének tűrésére kötelező rendelkezést tartalmazzon, és arra sem, hogy velük szemben a felperes törlési keresetet indítson és a törlési per feltételei fennállását (főként határidejét) sem kell vizsgálni. A perfeljegyzés azon joghatása tehát, mely szerint a perben hozott ítélet hatálya perbevonásuk nélkül is - kiterjed a további szerzőkre, rendkívül jelentős. Az árverési vevő sincs különleges helyzetben perfeljegyzéssel terhelt ingatlan vétele esetén, vagyis utóbb tulajdonjoga a per eredménye alapján törölhető és ilyen esetben maga köteles esetleges igényét külön perben érvényesíteni.

Összefoglalva: a perfeljegyzés és a végrehajtási jog bejegyzése két teljesen eltérő jogintézmény, az általuk elérni kívánt jogvédelmi hatás is más, ugyanakkor a két jogintézményben közös, hogy azok ingatlan-nyilvántartási bejegyzésétöl kezdve az ingatlanra vonatkozóan valamennyi jogszerzést függő hatályúvá, feltételessé tesznek. Míg a végrehajtási jog bejegyzésével ez a feltételes szerzés attól függ, hogy a végrehajtás célját illetőleg a végrehajtást kérő jogát ne sértse, addig a perfeljegyzés az ingatlanra vonatkozóan megindított per eredményétöl teszi függővé a jogszerzést.

${ }^{28}$ Az ingatlan-nyilvántartási joggyakorlat-elemző csoport összefoglaló véleménye, i. m., 120. 


\subsection{Az ingatlan-nyilvántartás jogvédelmi hatása törlési per esetében}

Az Inytv. 62. § (1) bekezdésének a) pont aa) alpontja szerint keresettel kérheti a bíróságtól a bejegyzés törlését és az eredeti állapot visszaállítását érvénytelenség címén az, akinek nyilvántartott jogát a bejegyzés sérti, továbbá az ügyész. Az új Ptk. 5:183. § alapján az ingatlan-nyilvántartási bejegyzés vagy feljegyzés törlésének a bejegyzés vagy feljegyzés alapjául szolgáló jogügylet érvénytelensége vagy a bejegyzés utólagos helytelenné válása miatt van helye. A Ptk. 5:184. § (1) bekezdése szerint a jogosultat megillető törlési vagy kiigazítási igény az ingatlan tulajdonjogát vagy az ingatlanra vonatkozó valamely jogot közvetlenül szerzővel szemben nem évül el. A (2) bekezdés alapján azzal szemben, aki közvetlenül a bejegyzés folytán szerzett jogot vagy mentesült kötelezettség alól, az érvénytelen bejegyzés törlése iránti pert addig lehet megindítani, amíg a bejegyzés alapjául szolgáló jognyilatkozat érvénytelensége megállapításának helye van.

A fentiektöl eltérően a közvetett szerzővel szemben, vagyis azzal szemben, aki a korábbi bejegyzés érvényességében bízva jóhiszeműen és ellenérték fejében szerez jogot, a Ptk. az ingatlan-nyilvántartás jogvédelmi hatása címszó alatt az alábbiak szerint rendelkezik. ${ }^{29} \mathrm{~A}$ törlési keresetet a jogsértő vagy utólag helytelenné vált bejegyzés alapján a bejegyzés helyességében és teljességében bízva, jóhiszeműen és ellenérték fejében jogot szerző harmadik személlyel szemben az anyagi jog szerinti jogosult az eredetileg érvénytelen bejegyzésről szóló határozat kézbesítésétől számított hat hónap alatt, a bejegyzés törlése esetén jogosulttá váló személy pedig az utólag helytelenné vált bejegyzés alapján történt jogszerzés bejegyzéséről szóló határozat kézbesítésétöl számított hat hónap alatt indíthatja meg, ha a határozatot részére kézbesítették. Ha kézbesítés nem történt, a törlési keresetet a bejegyzés hatályossá válásától számított hároméves határidő alatt lehet megindítani. E határidők elmulasztása jogvesztéssel jár.

A törlési per célja az érvénytelen bejegyzés törlése, melynek alapja rendszerint a közvetlen szerző féllel kötött, a bejegyzés alapjául szolgáló jogügylet (pl. adásvételi szerződés) érvénytelensége vagy létrejöttének hiánya.

A törlési per marasztalásra (az ingatlan-nyilvántartásba bejegyzett sérelmes jog törlésére és az eredeti ingatlan-nyilvántartási jog visszajegyzésére) irányul, a jogügylet érvénytelenségével, illetőleg létre nem jöttével kapcsolatos megállapítások az ítélet indokolásának részei. ${ }^{30}$

Az ingatlan-nyilvántartás közhitelességéből fakadóan az ingatlan-nyilvántartásban bízva, jóhiszeműen és ellenérték fejében szerzők védelme azon alapszik, hogy az ingatlan-nyilvántartás tartalmát a valósággal megegyezőnek kell tekinteni. Az ingatlan-nyilvántartás közhitelességéből eredő jogvédelmi hatás arra épül, hogy mindenki bízhat abban, hogy azok a jogok, amelyeket az ingatlan-nyilvántartás feltüntet, csakugyan megilletik a jogosultként bejegyzett személyt, és az ingatlanon csak azok

29 Ptk. 5:187. §.

30 A Legfelsőbb Bíróság Polgári Kollégiumának véleménye az ingatlan-átruházási szerződés érvénytelenségének megállapítása iránti és az ingatlan-nyilvántartási perek összefüggéseiről, 76., http://www.lb.hu/hu/ kollvel/legfelsobb-birosag-polgari-kollegiumanak-velemenye-az-ingatlan-atruhazasi-szerzodes (2017. 10. 01.). 
a korlátozások állnak fenn, amelyek oda be vannak jegyezve. A fenti bizalom elve a jóhiszeműen és ellenérték fejében jogot szerzőket védi. Az ingatlanra vonatkozóan jóhiszemű szerzőnek csak az minősül, aki nem tudott és nem is kellett tudnia az ingatlan-nyilvántartással ellenkező valóságos jogi állapotról. Könnyű belátni, hogy a fenti módon, az ingatlan-nyilvántartásban bízva jóhiszemüen és ellenérték fejében szerző jogvédelme és az eredeti tulajdonos érdekeinek védelme között konfliktus áll fenn. A jogalkotó a korábban hatályos Inytv. rendelkezéseinek és a jelenleg hatályos szabályozásnak (az Inytv. és a Ptk. vonatkozó részeinek) az ingatlan-nyilvántartás közhitelességéből eredő fenti jogvédelmi hatása (vagy jogvédelmi hatálya) időbeli eltolásával "oldja fel” a fenti konfliktust. A Ptk.-hoz füzött miniszteri indokolás szerint a bejegyzéshez füződő védelmi hatálynak az időbeli elcsúsztatása (a hat hónapos szubjektív és a hároméves objektív határidö) általában és rendes körülmények között megfelelő érdekkiegyenlítést biztosít a jóhiszemű szerző érdekeinek védelme (forgalombiztonság) és az eredeti tulajdonos érdekeinek védelme között, a védelmi hatály azonnali beállta továbbra sem indokolt. Ezt támasztja alá az is, hogy az ingatlan-nyilvántartás a bejegyzés alapjául szolgáló szerződés érvényességének vizsgálatára csak korlátozottan lehet alkalmas (például vizsgálható a bejegyzésre irányuló eljárásban a szerződés jogszabályba ütközése, de nem vizsgálható a szerződés érvénytelensége akarathibára, jó erkölcsbe ütközésre, a szerződés tartalmából nem nyilvánvaló más okokra tekintettel). ${ }^{31}$

A szabályozás gyökere a telekkönyvi nyilvántartás elterjedéséhez szorosan kapcsolódik, illetőleg ezen belül ahhoz, hogy ezen nyilvántartás nyilvános, bárki számára megtekinthető. A régi magánjogunkban ismert ún. „telekkönyvi elbirtoklás” intézménye és a jóhiszemü, ingatlan-nyilvántartásban bízva való jogszerzés lényege éppen abban van, hogy a „nem tulajdonostól” való szerzés a valódi tulajdonos bizonyos ideig való hallgatása esetén bekövetkezik, a tulajdonostól való szerzés magánjogi szabályait e rendelkezések a forgalom biztonsága érdekében áttörik. „A telekkönyvi szerzés azt jelenti, hogy valamilyen téves jogszerzés kerül feltüntetésre az ingatlannyilvántartásban és az idő múlásával - tehát a bejegyzést követő időmúlással - a téves bejegyzésnek megfelelő állapot jön létre." "32

A korábbi és a jelenlegi szabályozásban is hangsúlyozandó, hogy kizárólag a jóhiszemű és ellenérték fejében szerzőket részesíti a törvény védelemben a meghatározott határidő elteltével, vagyis mind a rosszhiszemü további jogszerzővel, illetőleg az ingyenes további jogszerzővel szemben a törlési kereset a 3 éves jogvesztő határidő elteltével is megindítható, az ily módon jogot szerzőt az időmúlás sem mentesíti a jogkövetkezmények alól, illetőleg velük szemben nem az ingatlan-nyilvántartás tartalma, hanem a tényleges jogi helyzet érvényesíthető.

Az ingatlan-nyilvántartásba bejegyzett tulajdonostól tulajdonjogot szerző további jogszerzővel szemben a törlési kereset alapja az, hogy az igényt érvényesítő által a közvetlen szerzővel kötött szerződés érvénytelen (illetőleg a bejegyzés más ok-

31 T/7971. számú törvényjavaslat a Polgári Törvénykönyvről, 544, http://www.parlament.hu/irom39/07971/07971. pdf (2017. 09. 14.).

32 Izsó Krisztina: A jóhiszemű szerzés. Polgári Jogi Kodifikáció, 2007/2, 15-21, http://ptk2013.hu/polgari-jogikodifikacio/izso-krisztina-a-johiszemu-szerzes-pjk-20072-15-21-o/151 (2017. 10. 06.). 
ból érvénytelen), és ezen alapszik az igényt érvényesítő azon joga, hogy a további jogszerzővel szemben is az eredeti állapot helyreállítását követelje. A törlési kereset megalapozottsága esetén a további jogszerző (vagy közvetett szerző) tulajdonjoga attól függetlenül törölhető, hogy ő maga jóhiszemüen járt el, illetőleg ebben a perben az ő bejegyzésének alapjául szolgáló jogügylet, illetőleg adott esetben hatósági vagy bírósági határozat nem képezi a vizsgálat tárgyát. lly módon kérdésként merül fel, hogy vajon a jóhiszemű árverési vevő tulajdonszerzése is - más módon való tulajdonszerzőkhöz hasonlóan - 3 év elteltével feltétlen-e, ekkortól élvezi-e az ingatlan-nyilvántartási jogvédelmi hatást. Figyelembe kell venni ugyanis a hatályos Ptk.-nak azt a már idézett szabályozását, ${ }^{33}$ mely megszüntette a különbséget az ingó és ingatlan hatósági árverésen való megszerzése között, és egységesen úgy rendelkezik, hogy aki a dolgot hatósági határozat vagy hatósági árverés útján jóhiszeműen szerzi meg, tulajdonossá válik, tekintet nélkül arra, hogy korábban ki volt a tulajdonos. Ennek következményeként ugyanis az adódik, hogy a jóhiszemú árverési vevő tulajdonszerzésével a védelmi hatás a Ptk. speciális rendelkezése folytán azonnal beáll.

\section{A végrehajtási jog bejegyzésének joghatásai zálogjoggal biztosított követelés esetén}

A végrehajtási jog bejegyzésének joghatásai a zálogjogosult zálogjoggal biztosított követelése vonatkozásában több szempontból is speciálisak, ezért erröl külön szükséges szót ejteni.

A zálogjogosult az adóssal szembeni követelését a végrehajtási eljárás keretén belül két módon érvényesítheti. Egyrészt, amennyiben a zálogjogból eredő követelése esedékessé válására tekintettel a zálogjoga megnyílt, ${ }^{34}$ úgy az adóssal szemben marasztaló bírósági határozat, illetőleg közjegyzői okiratba foglalt zálogjoggal biztosított követelés esetén a végrehajtási záradékkal ellátott közjegyzői okirat alapján kielégítési végrehajtást kezdeményezhet. Másrészt függetlenül attól, hogy a zálogjoggal biztosított követelése esedékessé vált-e vagy sem, a más által - pontosabban a zálogjoggal biztosított követeléstöl eltérő más követelésre nézve - az adóssal szemben indított végrehajtásba (mint alapvégrehajtásba) bekapcsolódhat.

Nem egységes az álláspont arra nézve, hogy abban az esetben, ha a zálogjog alapítását megelőzően az adós tulajdonaként nyilvántartott ingatlanra végrehajtási jog került bejegyzésre az ingatlan-nyilvántartásba, úgy a zálogjogosult az ekként indult, a végrehajtási jog bejegyzésének alapjául szolgáló végrehajtásba a zálogjoga alapján bekapcsolódhat-e vagy sem.

A Vht. rendelkezései ezt kifejezetten ugyanis nem zárják ki, továbbá az ilyen „későbbi” zálogjogosult végrehajtási eljárásba való bekapcsolódása önmagában a végrehajtási eljárás célját és a korábbi, végrehajtási joggal rendelkező végrehajtást

\footnotetext{
33 Új Ptk. 5:41. § (1) bek.

34 Új Ptk. 5:126. § (1) bek.
} 
kérő jogát nem sérti, ${ }^{35}$ mert a Vht. 170 . $§(3)$ bekezdése kifejezett rendelkezéssel a korábbi végrehajtást kérő javára lerontja a később bejegyzett zálogjogosultnak a zálogjogból egyébként eredő kielégítési elsőbbségre vonatkozó jogát. E rendelkezés alapján, ha a jelzálogjog ingatlan-nyilvántartásba történő bejegyzésére a végrehajtási jog ranghelyét követően került sor, a jelzálogjoggal biztosított követelést azon követelést követően lehet kielégíteni, amelyre e végrehajtási jog vonatkozik.

Ugyanakkor a fenti rendelkezés mellett álláspontom szerint kizárólag azon jelzálogjoggal biztosított követeléssel rendelkező végrehajtást kérő elégíthető ki, akinek az adóssal szemben a követelés esedékessé válása alapján megnyílt zálogjoga alapján a kielégítési végrehajtásra nézve kezdeményezett végrehajtható okirata van, mert a Vht. jelenlegi rendelkezései folytán egyéb okból arra nincs jogszabályi lehetőség, hogy a végrehajtási jog bejegyzését követően alapított jelzálogjog alapján az ilyen zálogjogosult a végrehajtási eljárásba bekapcsolódjon.

A Vht. 140/A. § alapján alkalmazandó Vht. 114/A. § (1) bekezdése szerint ugyanis a zálogjogosultnak a 114. § szerinti értesítés kézhezvételét követő 15 munkanapon belül előterjesztett kérelmére a végrehajtást foganatosító bíróság a soron kívül meghozott végzésével megállapítja a zálogjogosult kielégítési jogának megnyíltát, és engedélyezi, hogy a végrehajtási eljárásba bekapcsolódjék, ha a zálogjoggal biztosított követelés jogalapja és összegszerüsége - önálló zálogjog esetén a jogalap és az összegszerüség - nem vitatott. A (2) bekezdés szerint a kielégítési jog megnyíltát - szemben a végrehajtás általános feltételeivel - a bíróság az alapján állapítja meg, hogy a zálogtárgyat végrehajtási eljárás során lefoglalták. A kielégítési jog megnyíltát a foglalás ténye alapján nem lehet megállapítani, ha a zálogjogosult az adós hozzátartozója vagy olyan jogi személy, akinek az adóssal való viszonyában többségi befolyás áll fenn, illetve a zálogjog alapítására a gazdálkodó szervezet és tagja között került sor.

A jogszabály nyelvtani és logikai értelmezéséből az következik, hogy a bíróság a zálogjogosult kielégítési jogának megnyíltát a foglalás ténye alapján, vagyis az alapján állapítja meg, hogy a végrehajtási jogot az ingatlan-nyilvántartásba bejegyezték. Ugyanakkor a végrehajtási jog bejegyzését követően az ingatlan-nyilvántartásba bejegyzett jelzálogjog vonatkozásában fogalmilag kizárt, hogy az ennél korábban bekövetkezett végrehajtási jog bejegyzése (az ingatlan lefoglalása) megnyitotta volna a még létre sem jött (az ingatlan-nyilvántartásba még be nem jegyzett) zálogjogból eredő kielégítési jogot.

A zálogjog speciális helyzete a végrehajtási eljárásban továbbá más oldalról abban jelentkezik, hogy a zálogjogosulti követelés végrehajtása érdekében kért végrehajtási jog bejegyzését az Inytv. vhr. 21. § (3) bekezdésében foglaltak szerint a jelzálogjog rangsorában kell elintézni, attól függetlenül, hogy ki az ingatlan tulajdonosa. ${ }^{36}$

Az adós tulajdonaként nyilvántartott ingatlanra a végrehajtási jog bejegyzésével kapcsolatban már a dolgozat korábbi részében utalás történt arra, hogy a végrehajtási jog bejegyzésének soron kívül történő intézése nem jelent az ingatlan-nyilvántartási rangsortól eltérő ügyintézést, a kérelmeket, illetőleg megkereséseket az

35 Vht. 138. § (6) bek.

36 40/2014. Számú közigazgatási elvi határozat. 
iktatás rangsorában kell elintézni. Amennyiben a végrehajtási jog bejegyzése iránti végrehajtói megkeresés földhivatali iktatásának időpontjában az ingatlan már nem az adós tulajdonát képezi, úgy az ilyen kérelmet a földhivatal elutasítja az Inytv. 49. § (1) bekezdése alapján.

A zálogjoggal biztosított követelésre vonatkozó végrehajtási jog bejegyzésére azonban a fentiektől eltérő, speciális rendelkezést tartalmaz az Inytv. vhr. 21. § (3) bekezdése, összhangban a zálogjogra vonatkozó anyagi jogi szabályokkal, melynek lényege szerint a zálogjog nem személyhez, hanem az azzal terhelt dologhoz mint biztosítékhoz kötődik. A régi Ptk. 256. § (1) bekezdése és a hatályos Ptk. 5:86. § (2) bekezdése alapján a zálogtárgyra a kielégítési jogot - ha törvény eltérően nem rendelkezik - az elzálogosítás után szerzett jogok nem érintik.

A Kúria fenti döntése indokolásában mindezek alapján rámutatott, hogy amennyiben a végrehajtói megkeresés jelzálogjoggal biztosított követelésre vonatkozó végrehajtási jog bejegyzésére irányul, úgy az Inytv. vhr. 21. § (3) bekezdése értelmében a megkeresésnek nem a megkeresés érkezésekor alapított rangsorban, hanem a jelzálogjog bejegyzés rangsorában kell eleget tenni, és ezt a rendelkezést az Inytv. 49. § (1) bekezdése nem írja felül. ${ }^{37}$

\section{5. Összefoglalás}

A hatósági árverésen történő tulajdonszerzésre, a végrehajtási igényper megindíthatóságára, valamint a végrehajtási jog és a perfeljegyzés joghatásaira, végül a törlési perekre tekintettel az alábbi fontosabb megállapításokat tehetjük.

A hatósági árverésen történő tulajdonszerzés eredeti szerzésmód függetlenül attól, hogy a vagyontárgy jellege szerint (ingó, ingatlan) a szerzésre eltérő rendelkezések vonatkoznak.

A végrehajtási igényper megindítására nincs keresetindítási határidő, ugyanakkor az igénykereset nem vezethet sikerre, ha a benyújtása a lefoglalt vagyontárgy végrehajtási értékesítéséből befolyt összeg felosztását követően, a végrehajtási eljárás befejeződése után történt. Ha a végrehajtást kérővel szemben az igénylő elmulasztja előterjeszteni a végrehajtási igénykeresetet, illetve azt késedelmesen terjeszti elő, akkor igényét a jóhiszemű árverési vevővel szemben annak tulajdonjoga bejegyzését követően nem érvényesítheti, mivel az árverési vevő abszolút (teljes és azonnali) védelmet élvez.

A végrehajtási jog és a perfeljegyzés bejegyzése esetében közös vonás, hogy azok ingatlan-nyilvántartási bejegyzésétől kezdve az ingatlanra vonatkozóan valamennyi jogszerzést függő hatályúvá, feltételessé tesznek. Míg a végrehajtási jog bejegyzésével ez a feltételes szerzés attól függ, hogy a végrehajtás célját, illetve a végrehajtást kérő jogát ne sértse, addig a perfeljegyzés az ingatlanra vonatkozóan megindított per eredményétől teszi függővé a jogszerzést. Ebből kifolyólag a végrehajtási jog bejegyzését követően, noha az adós rendelkezhet az ingatlannal, az ingatlanon így jogot szerző jogszerzése feltételes: köteles türni az árverést, tulajdon-

37 40/2014. számú közigazgatási elvi határozat. 
jogának törlését, az ingatlanügyi hatóság az árverési vevő tulajdonjoga bejegyzését külön eljárás megkövetelése nélkül elvégzi. Perfeljegyzést követően pedig az ingatlan - végrehajtás keretében történő - árverezésekor az árverési vevő csak a per eredményétől függő hatállyal szerezheti meg az ingatlan tulajdonjogát.

A végrehajtási jog bejegyzésének joghatásai a zálogjogosult zálogjoggal biztosított követelése vonatkozásában több szempontból is speciálisak. Egyrészt arra nincs jogszabályi lehetőség, hogy a végrehajtási jog bejegyzését követően alapított jelzálogjog alapján az ilyen zálogjogosult a végrehajtási eljárásba bekapcsolódjon. Másrészt a zálogjogosulti követelés végrehajtása érdekében kért végrehajtási jog bejegyzését a jelzálogjog rangsorában kell elintézni, attól függetlenül, hogy ki az ingatlan tulajdonosa.

A hatályos Ptk. 5:41. § (1) bekezdése rendelkezései alapján, amely egységes szabályozást tartalmaz az ingók és az ingatlanok hatósági árverésen való tulajdonszerzésére, jogalkalmazási kérdésként merül fel, hogy hogyan alakul a gyakorlat a törlési perekre vonatkozóan. Van-e helye a jóhiszemü árverési vevővel szemben törlési per indításának, ha az ingatlanárverésen megszerzi az ingatlan tulajdonjogát, vagy - miután szerzése feltétel nélküli eredeti szerzésnek minősül - a vele szembeni törlési per eredményes indításának lehetöségét a hatályos Ptk. idézett rendelkezése mint speciális rendelkezés kizárja. Álláspontom szerint jóhiszemű árverési vevő esetén az ún. védelmi hatás azonnal beáll, így vele szemben eredményes törlési per nem indítható.

\section{Abstract}

The subject of the study is the realization of real estate, which is not examined in the traditional way but within the scope of the implementing law, but as a legal institution affecting several jurisdictions, focusing on the ownership of the auction buyer. In addition to the method of obtaining ownership based on the official auction, it analyzes in detail the possibilities of obtaining from the non-owner in the official auction and in the light of the judicial practice, the legal effects of registering the enforcement right and the note are taken into account. 